Article

\title{
Social Trust Formation and Credit Accessibility-Evidence from Rural Households in China
}

\author{
Tong Zhang ${ }^{1}$, Huiting Liu ${ }^{2, *}$ and Pinghan Liang ${ }^{3}$ \\ 1 National School of Agricultural Institution and Development, South China Agricultural University, \\ Guangzhou 510642,China; tongzhang@scau.edu.cn \\ 2 College of Economics and Management, South China Agricultural University, Guangzhou 510642, China \\ 3 Center for Chinese Public Administration Research and School of Government, Sun Yat-sen University, \\ Guangzhou 510275 China; liangph5@mail.sysu.edu.cn \\ * Correspondence: huiting_liu@stu.scau.edu.cn
}

Received: 5 December 2019; Accepted: 13 January 2020; Published: 16 January 2020

check for updates

\begin{abstract}
Trust as a form of social capital plays an important role in improving the cooperation between agents, especially in credit lending activities. Trust building has attracted significant research interest, and gift giving has been shown to be one of its main drivers. Nonetheless, the mechanism of gift giving in the formation of trust networks and the channels through which gift giving and trust affect cooperation require further investigation. In this paper, we first separate social trust into community trust and personal trust, and we examine how gift giving affects the formation of each level of trust. We then explore how trust and gift giving affect rural households' access to formal and informal sources of credit. Our results show that gift giving mainly helps in forming trust at the personal level rather than the community level. In turn, personal and community trust can facilitate access to informal and formal sources of credit, respectively. In addition, personal trust facilitates access to informal loans for consumption and medical expenses but not production. Overall, our findings show that gift giving is mainly used to build personal trust which facilitates access to informal lending for risk-sharing purposes.
\end{abstract}

Keywords: social capital; trust; credit accessibility; gift giving; informal lending; community trust; personal trust; network formation; risk sharing

\section{Introduction}

Following the seminal work of Putman, numerous studies have shown that social capital can reduce poverty and facilitate rural development [1-4]. Social capital, which is manifest in informal institutions such as trust, mutual help, and gift exchanges, continues to be of value because it provides functions that the formal institutions cannot deliver. Thus, social capital can be regarded as a valuable social resource. One of the most important function of social capital is to promote cooperation between individuals or organizations. Cooperation can be embodied in not betraying, abiding by the contract, enforcing the terms in case of high-risk situations, and so on. Such cooperative behavior often requires trust as a basis, which can be regarded as one party's expectation about how the other party would try its best to fulfill commitments on cooperation in the future. Even if there is an official contract supervision agency, the incompleteness of the contract and unexpected risks may also lead to potential breach of contract, making it difficult for the law to protect the interests of all parties. Especially in underdeveloped rural areas that suffer from weak formal institutions, an immature market environment, and a high cost of law enforcement, people are highly reliant on social capital in 
enforcing commitments and risk-sharing arrangements by ensuring long term reciprocal relationships between agents as a form of cooperation $[5,6]$.

In developing countries, the low income usually cannot allow rural households to save enough in order to meet the procurement requirement of variable production inputs or to prepare for unexpected accidents. In China, an example of developing country, small-scale farming families dominate the agricultural production and operate on average about 0.53 hectares of farmland. Statistics show that there are more than 200 million rural households and 570 million permanent rural residents in China, accounting for around $40.1 \%$ of the country's total population (National Bureau of Statistics, 2018). About 17 million rural people, $3.0 \%$ of the total rural population, live below the poverty line of $\$ 327$ USD per person per year. These realities determine that the capital demand of Chinese rural households is characterized by high frequency and small quantity. Thus, access to credit is critical not only for the economic development of rural residents but also for their survival.

Credit accessibility refers to the ease or difficulty of acquiring credit by borrowers for purposes such as enhancing business performance or dealing with risks. There are mainly two channels from which farmers seek for loans, informal channels such as relatives, friends and acquaintances and formal channels such as banks. The main financial institutions in rural China include Rural Credit Cooperatives, Rural Cooperative Bank, Rural Commercial Bank, and Agricultural Bank of China. However, these banks and financial institutions lend more to rural enterprises than to rural households. They are reluctant in lending to rural households for a variety of reasons including the lack of collateral for farmers, the high cost of pre-loan investigation and debt collection. As a result, farmers often rely heavily on informal channels of borrowing, such as acquaintances in social networks.

Whether lenders provide financial support depends on the extent to which they believe the money will be repaid. Therefore, the borrowers need to establish trust with the lenders in order to obtain funds. Trust can play roles in different levels of social structure such as in community level and individual level. Different levels of trust may not accumulate in the same way and may be heterogeneous in promoting loan contracts.

Previous literature has found that gift giving is one of the key factors to promote lending [7]. It is generally believed that gift giving is a kind of social custom or cultural behavior, but it also has economic incentives and can make the recipient more willing to help, such as lending money. According to a broad national survey, gift giving accounts for a considerable portion of the funds transfer in the daily lives of rural households, close to around 7\% of their annual income (China Labor-force Dynamic Survey, 2016). However, it is a relatively small share compared with borrowing, which is more than the total income of households.

Previous studies have not made in-depth analysis on whether gift giving promotes cooperation by strengthening emotional links or transmitting signals of economic capacity by building trust relationships, or whether the gift itself plays a role in facilitating loan agreements. In particular, whether gift giving can help the construction of community or personal trust, and how these two types of trust affect the formal and informal channels of credit, needs further investigation.

This paper makes the following contributions to the literature. First, this paper differentiates social trust at the community level from trust at the individual level and shows how gift giving affects these two types of trust through different channels. Second, social trust at the community and individual level play different roles when households seek credit. Finally, the co-existence of formal and informal borrowing channels indicates that these two levels of trust play complementary role in facilitating the sustainability and development of the rural economy.

The rest of this paper is organized as follows. Section 2 reviews the literature. Section 3 presents the models and dataset. Section 4 examines how gift giving leads to the formation of different types of social trust at the community and personal levels. This section also discusses how gift giving and the different levels of trust affect credit accessibility through heterogeneous channels and in relation to different borrowing purposes. Finally, Section 5 concludes the paper. 


\section{Literature Review}

Social capital has complex connotations, and people generally maintain or accumulate it through relationship networks. Social networks are bonded with attributes such as trust, affection, and signaling. Trust is the leading attribute of social capital and is believed to serve as an intervening variable in improving cooperation, lending behavior, and investment [8-10]. In addition to being manifested horizontally through the strong relationships between family members and weak relationships between acquaintances, trust can be developed vertically at the individual level through repeated interaction and at the community level through the development of general beliefs based on upbringing and social learning [11]. Shoji et al. study the mechanism of social capital formation in an imperfect credit market and show that the investment decline in social capital of credit constraint households will reduce three levels of trust, which are general trust, trust in villagers and business partners [12]. Using data on Small Business Administration (SBA) loans originated and held by rural and urban community banks, Deyoung et al. demonstrate social capital brought by acquaintance society can reduce the default rate of loans from rural and community banks, and the default rate of borrowers in the community is lower than that of borrowers outside the community [13]. Thus, from a social structure perspective, trust can be separated into two vertical levels-community trust and personal trust. These different levels of trust may play heterogeneous functions for individuals. In addition, Kinnan and Townsend find channel effect exists by showing that kinship network improves investment financing instead of consumption comparing to formal financial institution like banks [14].

Because forming or enforcing trust within a social network has an opportunity cost, individuals need to consider the trade-off between the benefits and costs based on their social economic situation. Concerning social network formation, studies show that typical ways range from endogenous means such as kinship to exogenous means such as gift giving and mutual help [14,15]. Individuals and communities possess different levels of social capital that they inherit from their predecessors or accumulate through their own efforts. Besides the exogenous networks formed through consanguinity and marriage [16], individuals can also form endogenous networks through gift giving.

Gift giving has been widely practiced through history and can be regarded as a mean of social capital accumulation. Although gift giving usually strengthens the intimate relationships between people, it must be associated with a strong economic function; otherwise, the costs would not have been sustainable over such a long period of history. Because of the limited commitment problem exists in all forms of favor exchange [17], the helper needs to know whether the requester is trust worthy enough in offering a return or paying back the money. In many rural areas, people may use gift exchange as a signaling mechanism to form trustable social networks and thus resolve the commitment problem [15]. Besides constructing new social links, people can also differentiate the relationships within endogenous kinship networks by exchanging gifts of different value. The strength of a relationship makes a huge difference when people seek to determine who they can turn to for help or ask for a loan. Therefore, it is worth examining how gift giving strengthens social trust and facilitates informal reciprocal commitment.

An important purpose of gift giving is to accumulate social resources in case there is a need for financial borrowing. Informal loans can finance rural households by serving as means to share risk or seek profit. Formal and informal sources of finance typically coexist in markets with weak legal institutions and low levels of income [18,19]. For example, $70 \%$ of all poor borrowers obtain credit from both sectors in Delhi, India [20]. Subject to low income, most of these borrowers are unable to save enough to prepare for medical, education, and marriage expenses. Production, investment, and consumption also require capital support. As a result, rural households with poor access to formal credit markets may have to constantly invest in social capital to secure access to informal credit sources [21,22]. Numerous studies have shown the important role that social networks play in making available informal credit and other types of mutual insurance [23-27].

Informal lending among rural households can be looked as a mean of risk sharing. As one of the most common long-term reciprocal trust-based social relationships, risk sharing is popular among the 
rural populations of developing countries where underdeveloped service markets and low incomes make service costs unaffordable. Risk sharing is also an important resource for rural households in high-risk underdeveloped environments in which local residents are unable to save enough to resist shocks such as bad weather, illness, and major life events. In these areas, risk sharing is mostly conducted through informal loans and individual labor sharing agreements. These shocks tend to be asynchronous, and they enable the members of social networks to share risks. Kimball states that theoretically farmers with the same income distribution can reduce their risk by sharing it with the whole community [28]. Empirical studies show that risk can be shared within exogenous kinship networks and endogenously generated networks via mechanisms such as marriage, mutual help, and gift giving but not in a completely way as Kimball predicts $[24,25,29,30]$.

Informal lending social network is frequently adopted to study the effect of social capital or trust on risk sharing behavior among rural households. With a theoretical framework, Madestam shows that formal and informal lending channels can coexist in underdeveloped credit markets [31]. This phenomenon also proved with empirical findings and an extreme case shows that there are even as high as $95 \%$ of all very poor borrowers access credit from informal channels when banks are available in Hyderabad, India $[14,18,19,32,33]$. It is worth to investigate under what kind of circumstances people choose among different financial channels and how social capital play roles to facilitate lending activities.

Although a number of studies explore the impact of social capital on credit lending, very few show the mechanism of social capital formation and the path through which it affects credit accessibility. Thus, further research is needed on the mechanisms underlying the formation of social networks and informal credit lending. In addition to directly examining the effect of gift expenditure on credit accessibility [7], it is worth investigating the subtler mechanisms of gift giving, such as the motivations behind it and the channels through which it works. This paper examines how gift giving is used as a tool to influence the accumulation of social capital at the community and individual levels, and how these two levels of social trust affect the economic decisions of households using lending as an example.

\section{The Model and Data}

The mechanism of how social trust forms and then affects the economic behavior of households is worth investigating. Trust acts as a mediating attribute in enforcing reciprocal risk-sharing behavior, while gift giving can also send signals in relation to constructing new or enforcing pre-existing social links. The recipient of a gift and its value are factors that people consider when using gifts to maintain or initiate relationships. When facing an economic shock caused by capital requirements, households decide who they can rely on and how much they need to borrow. In turn, the households they ask will decide whether they will provide the loan.

\subsection{The Model}

Different from the literature, this paper differentiates between personal trust and community trust. Compared with the general social environment that social trust reflects, individuals measure the trustworthiness of different people based on their relationships with them, and they must continually maintain, enforce, and adjust these beliefs through their interactions. Gift giving is frequently used to show a willingness to maintain a relationship or construct a new network link with someone. Gift giving as a form of social exchange mostly occurs in one-to-one personal relationships. Gift giving may serve different purposes, and it can play a role in collective actions. For example, when a poor household faces an unfortunate event, the village leaders may call on the villagers to provide goods or money to help the family. In this case, the gift transfer will increase community trust at the individual and collective levels and influence the affective associations between individuals. Later, if the help providers or gift givers face difficulties, the receiver will have a moral obligation to return the kindness in some way. 
This paper examines how gift giving helps to form and maintain social capital in relation to trust at the community and individual levels. Community level trust is evaluated in terms of the average level of trust in the community. For personal trust, it is assumed that the more often mutual help occurs between one agent and other villagers, the more mutual trust exists between them. Thus, the frequency of mutual help between one agent and other households is included in the questionnaire to indicate the individual levels of trust.

Because the villagers are assumed to behave in a reciprocal rather than altruistic manner, whether an individual can obtain a loan depends on whether he or she is deemed to be trustworthy. We use credit access channels, namely formal institutions and informal personal loans, to evaluate the effect of social capital. In addition, the purposes for the loans are differentiated into production, house construction, medical care, education, consumption, and other factors. Although all of the personal loans are based on informal commitments, investments in production and housing can generate valuable outputs, which the lenders may use as a kind of collateral. The loans obtained for other purposes are mainly based on trust or risk-sharing motivations.

In the empirical model, we first test whether people give gifts to accumulate or maintain social capital at the community trust or personal trust levels. We then test whether the effects of the two levels of trust along with gift giving help with credit accessibility via the formal and informal channels.

\subsubsection{Social Trust Formation: Community Trust and Personal Trust}

Because villagers are assumed to be reciprocally rather than altruistically minded, whether an individual can obtain a loan depends on whether he or she is deemed to be trustworthy and whether the creditor is willing to make an informal commitment based on the interaction. Gift giving can be used to help form social trust or commitment as a cost of set up or to maintain social links and send signals. We first distinguish personal trust from community trust. Because the independent variable indicating the strength of social trust is an order variable, we use an ordered probit model to estimate the impact of gift giving on the formation of social capital, which is specified as

$$
S_{i, k}=\beta_{0}+\beta_{1} G_{i}+\beta^{\prime} \mathbf{X}_{\mathbf{i}}+\zeta_{\mathrm{i}}
$$

where $S$ is social trust and its subscript, $k=c, p$, indicates community trust and personal trust, respectively. Community level trust $S_{c}$ is measured by the respondents' answers to a question about how much they trust their neighbors and other residents in the village (options: $1=$ strongly distrust, $2=$ distrust, $3=$ generally trust, $4=$ trust, $5=$ strongly trust). Personal trust $S_{p}$ is measured by a question about frequency of the mutual help between households and other residents in the village (options: $1=$ seldom, $2=$ few, $3=$ general, $4=$ frequent, $5=$ very frequent). $G$ is the amount of gift giving of a household, $X$ includes other control variables, and $\zeta$ is the error term.

We assume that people use gifts as tools to maintain or enforce social relationships. Gifts may not only help facilitate trust between individuals but also increase the social capital at the community level by lifting the overall level of trust. Here, we propose hypothesis H1.

Hypothesis 1a (H1a). The gift giving of households increases social trust at the community level.

Hypothesis $\mathbf{1 b} \mathbf{( H 1 b ) . ~ T h e ~ g i f t ~ g i v i n g ~ o f ~ h o u s e h o l d s ~ i n c r e a s e s ~ s o c i a l ~ t r u s t ~ a t ~ t h e ~ i n d i v i d u a l ~ l e v e l . ~}$

\subsubsection{Credit Accessibility Affected by Community Trust and Personal Trust}

We explore the effect of social capital on credit accessibility by testing whether social capital helps households to access credit and whether social capital affects the credit accessibility channels. 
Because we only include households with loans in the sample, to avoid sample selectivity bias, we use the Heckman selection model [14]. The first stage of the selection model can be written as

$$
\operatorname{Loan}_{i}^{*}=\gamma_{0}+\gamma_{1} S_{i, k}+\gamma^{\prime} Z_{i}+\gamma_{i}
$$

The binary probit regression is used to estimate the effects of social trust on loan accessibility. Here, $\operatorname{Loan}_{i}{ }^{*}$ is assumed to be a latent variable representing the existence of a loan, $\mathbf{Z}_{\mathrm{i}}$ refers to a vector of the control variables, and $v_{i} \sim \mathrm{N}(0,1)$ is the error term. Note that $\operatorname{Loan}_{i}{ }^{*}$ is not observed, and we can only observe $\operatorname{Loan}_{i}$. If $\operatorname{Loan}_{i}^{*}>0, \operatorname{Loan}_{i}{ }^{*}=1$; and if $\operatorname{Loan}_{i}{ }^{*} \leq 0, \operatorname{Loan}_{i}{ }^{*}=0$.

Let the variable Amount represent the borrowing amount (in log form); then, Amount $_{i}=\theta_{0}+\theta_{1} S_{i, k}$ $+\theta^{\prime} X_{i}+\mu_{i}$, where $\mu_{\mathrm{i}}$ is a normally distributed error term with a mean of zero and standard deviation $\sigma$. We only observe Amount $i_{i}$ when $\operatorname{Loan}_{i}{ }^{*}$ is greater than zero. We assume that the error terms $\mu_{i} \sim \mathrm{N}(0$, $\left.\sigma^{2}\right)$, corr $\left(\mu_{i}, v_{\mathrm{i}}\right)=\rho$, where $\rho$ represents the correlation between the two error terms to be estimated. The parameter $\lambda=\sigma \rho$, known as the inverse Mills ratio, is the estimated selection coefficient (Greene, 1993). Then, the second-stage regression model can be written as

$$
E\left(\text { Amount }_{\mathrm{i}} \mid \operatorname{Loan}_{\mathrm{i}}^{*}>0\right)=\theta_{0}+\theta_{1} S_{i, k}+\theta^{\prime} \mathbf{X}_{\mathrm{i}}+\theta_{\lambda} \hat{\lambda}+\varepsilon_{i} .
$$

In the first step, the probit regression is used to model the sample selection process in Equation (2), and the inverse Mills ratio $\lambda$ is calculated based on the probit regression results. In the second step, the inverse Mills ratio is added to the multiple regression analysis as an independent variable and ordinary least squares is used to provide the consistent parameter estimates in Equation (3). According to Wooldridge (2006), the explanatory variables in Equation (3) should be a subset of the explanatory variables in Equation (2). Thus, at least one explanatory variable in Equation (2) does not appear in Equation (3). We also include variables that refer to the existence of banks, cooperative organizations, and the distance to the nearest town in Equation (2), which are excluded in Equation (3). We consider these variables to have a direct effect on the occurrence of a loan, but less effect on the borrowing amount.

Furthermore, we explore the influence mechanism of gift giving on the borrowing amount using a causal mediation analysis $[34,35]$. Community level trust and personal trust may be potential mediators of the effect we wish to estimate. Thus, to identify the casual direct effect, we need to posit and fit regression models for the mediator $S_{i, k}$ and the outcome of interest $\left(\right.$ Amount $\left._{\mathrm{i}} \mid \operatorname{Loan}_{\mathrm{i}}{ }^{*}>0\right)$. The mediator model is listed as Equation (2). The outcome is modeled as

$$
E\left(\text { Amount }_{\mathrm{i}} \mid \operatorname{Loan}_{\mathrm{i}}^{*}>0\right)=\theta_{0}+\theta_{1} S_{i, k}+\theta_{2} G_{i}+\boldsymbol{\theta}^{\prime} \mathbf{X}_{\mathrm{i}}+\theta_{\lambda} \hat{\lambda}+\varepsilon_{i}
$$

where the borrowing amount is a function of the mediator $S_{i, k}$ and gift expenditure, and all of the covariates. A mediator variable can either account for all or some of the observed relationship between gift giving and the borrowing amount. If the inclusion of the mediation variables eliminates the effect of gift giving on the borrowing amount and the coefficient of variable $G$ is insignificant, there exists full mediation of social trust for gift giving. When the inclusion of the mediation variables only weakens the effect of gift giving, there exists partial meditation. The partial mediation effect of gift giving implies that giving gifts not only increases the level of social trust, which helps form the belief in fulfilling the commitment and affects the borrowing amount through the other functions it brings.

Social trust at different levels, such as community trust and individual trust, is worth studying -in particular, how they influence families to seek resources from formal institutions or through informal channels. Monetary loans are often considered an effective means of studying social networks because there is a relatively clear record of where and how much a household borrows. Rural households usually have two main ways to borrow money: formal lending from banks and financial cooperatives, and informal lending from individuals based on informal commitments. According to Chinese property law, rural households do not possess full property rights on their farmlands and estates and thus 
usually cannot use them as guarantees. The lack of a personal credit evaluation system for Chinese farmers also makes the formal and informal lenders heavily dependent on trust. In addition, the different levels of trust play different roles in these financial channels. Thus, we propose hypothesis $\mathrm{H} 2$.

Hypothesis 2a (H2a). Personal trust helps households access credit through informal channels.

Hypothesis 2b (H2b). Community trust helps households access credit through formal channels.

Different from formal institutions that pursue profits, informal loans are mostly a way of sharing risk and providing help. Moreover, when households require loans to deal with costs such as medical or tuition fees rather than investments, the householders will have difficulty accessing the credit through formal channels such as banks. We propose hypothesis H3.

Hypothesis 3 (H3). Personal trust helps more in unprofitable loans.

\subsection{The Data}

This paper uses data from the China Labor-force Dynamic Survey (CLDS) conducted by the Center for Social Science Survey at Sun Yat-sen University. The CLDS uses a probability sampling method with multi-stages and multi-levels and is proportional to the labor force in China. This biennial tracking survey is taken on rural and urban households in China and includes cross-sectional questions at the individual, family, and community levels.

The CLDS completed the national baseline survey in 2012, with the first follow-up survey conducted in 2014 and the second follow-up survey in 2016. The 2016 CLDS survey was carried out in 29 provinces, municipalities, and autonomous regions across the country, excluding Hong Kong, Macao, Taiwan, Tibet, and Hainan, and comprised 401 questionnaires on village communities, 14,226 family questionnaires, and 21,086 questionnaires on individuals aged 15 to 64 . The final sample comprises 231 villages, 7067 households, and 13,319 individuals.

\subsection{Variables}

Table 1 provides the descriptive statistics of the variables, including the gift amount, levels of community trust and personal trust (as indicated by the frequency of mutual help), and money borrowed. The variables used in our regression analysis are separated into the following categories: social capital, family demographics, production, loan, and community condition.

\subsection{Descriptive Statistics}

The average individual income of the respondents is 20,429 yuan, which is close to the national level in 2015 (21,966 yuan). The average level of educational attainment is middle school. More than $90 \%$ respondents are local registered residents in their village, there is an even distribution of gender among the samples, and $80 \%$ of the respondents are primary married. The average age of the respondents is 46 years and most of them (about $80 \%$ ) report being healthy. The household income per capita is RMB 10,089 , which is lower than the national average of rural residents in 2015 (11,422 yuan). The average household comprises five family members, while only $27 \%$ of rural residents have a stable job. About $64 \%$ of households are engaged in agricultural production, $40 \%$ of households engage in mechanized agricultural production to some degree, and the average arable land owned is $6.57 \mathrm{mu}$. The average population of the villages is 2279 . On average, about $32 \%$ of the labor force in these villages works outside the village. The ratio of permanent residents to the registered population is 1.17 , which means the numbers of inflowing migrants outweigh the numbers of outflowing migrants. The sample villages have five enterprises on average and account for about $62 \%$ of the road burden. The surveyed villages are evenly distributed in the Eastern, Middle, and Western regions of China. 
Table 1. Data statistics.

\begin{tabular}{|c|c|c|c|}
\hline Variables & Description & Mean & $\begin{array}{l}\text { Standard } \\
\text { Deviation }\end{array}$ \\
\hline \multicolumn{4}{|l|}{ Key variables } \\
\hline gift expenditure in 2015 (yuan) & yuan (RMB) & 3077 & 5027 \\
\hline mutual help (Personal trust) & $\begin{array}{l}1=\text { seldom, } 2=\text { few }, 3=\text { general, } 4=\text { frequent, } 5 \\
=\text { very frequent }\end{array}$ & 3.510 & 0.980 \\
\hline existence of loan & $1=$ yes $; 0=$ no & 0.360 & 0.480 \\
\hline borrowing amount & yuan (RMB) & 63,462 & 110,000 \\
\hline household income in 2015 & yuan (RMB) & 45,559 & 63,907 \\
\hline existence of bank loan & $1=$ yes $; 0=$ no & 0.240 & 0.420 \\
\hline existence of informal loan & from sources other than bank, $1=$ yes; $0=$ no & 0.890 & 0.310 \\
\hline existence of both bank loan and informal loan & $1=$ yes $; 0=$ no & 0.140 & 0.350 \\
\hline existence of informal loan for medical treatment & $1=$ yes $; 0=$ no & 0.160 & 0.360 \\
\hline \multicolumn{4}{|l|}{ Household characteristics } \\
\hline education of householder & $1-11$, incremented in order & 2.610 & 1.130 \\
\hline householder belongs to the minority & $1=$ yes $; 0=$ no & 0.130 & 0.330 \\
\hline householder is a party member & $1=$ yes $; 0=$ no & 0.090 & 0.280 \\
\hline self-rated health status of householder & $1-5$, a better health in order & 3.510 & 1.050 \\
\hline householder engage in agricultural production & $1=$ yes $; 0=$ no & 0.440 & 0.500 \\
\hline householder has a full-time job & $1=$ yes $; 0=$ no & 0.280 & 0.450 \\
\hline householder is a local registered resident & $1=$ yes $; 0=$ no & 1.120 & 0.550 \\
\hline number of family members living together & & 4.910 & 2.050 \\
\hline household income per capita & yuan (RMB) & 10,070 & 15,083 \\
\hline surname diversity & $\begin{array}{l}\text { calculate based on the largest surname } \\
\text { proportions }\end{array}$ & 67.03 & 27.52 \\
\hline existence of lineage hall & $1=$ yes $; 0=$ no & 0.240 & 0.430 \\
\hline registered populations & person & 2275 & 1863 \\
\hline standard deviation of household income & yuan (RMB) & 43,409 & 37,681 \\
\hline ratio of poverty families & $\%$ & 0.100 & 0.100 \\
\hline average income per capita in village & yuan (RMB) & 9821 & 10,674 \\
\hline ratio of population engaged in non-agriculture & $\%$ & 0.210 & 0.290 \\
\hline ratio of outflow labor force to the total labor force & $\%$ & 0.430 & 0.950 \\
\hline number of enterprises in village & & 5.140 & 15.050 \\
\hline average education level of villagers & $1-11$, incremented in order & 4.510 & 1.760 \\
\hline plain & $1=$ yes $; 0=$ no & 0.470 & 0.500 \\
\hline eastern regions & $1=$ yes $; 0=$ no & 0.420 & 0.490 \\
\hline middle regions & $1=$ yes $; 0=$ no & 0.280 & 0.450 \\
\hline northern regions & $1=$ yes $; 0=$ no & 0.460 & 0.500 \\
\hline
\end{tabular}

Table 1 shows that the value of the average gift is around 3000 yuan, which accounts for about $6.8 \%$ of the households' overall income. In contrast, the average household debt is as high as 63,000 yuan and accounts for about $139 \%$ of the total household income. Among the households with loans, $89 \%$ of them borrow via informal channels. Thus, compared with loans, gift giving only accounts for a very small ratio of income and should be regarded as a tool for network building instead of the main risk-sharing tool. Gift giving facilitates the initiation and maintenance of social relationships and can be implemented at little cost. Part of the function of gift giving is to increase the trust between agents, and it may also make the recipient feel morally obliged to return the favor in the future. Besides the gift giving related variables, other social capital indicators are included as control variables, such as a political background as a party member, education level, and belonging to an ethnic minority. 
The financial variables include whether households have debts and the quantity, source, and purpose of the debts. Informal lending plays an important role in the daily life of rural households. According to Table 1, the mean debt is higher than the annual household income. Other financial related variables, such as having a stable income or formal insurance, that may affect risk-sharing behavior and willingness are also included.

The demographic characteristics are recorded on the individual, household, and village levels. Other important individual-level data about the householders are also considered, such as annual income, education attainment, whether the respondent is a locally registered resident, gender, marital status, age, and self-rated health status.

The household characteristics in the model include household income per capita, number of family members living together, the ratio of family members with stable jobs, whether the household is engaged in agricultural production, level of agricultural mechanization, and the arable land owned. Because the income, arable land owned, and population variables may contain heteroscedastic, zero, or minimum values, the regressions use the logarithmic values of these variables.

As the most important activity and source of income, agricultural production affects household behavior in many ways. The working intensity for agricultural production is unsteady, especially for grain crops. Special production phases such as rice transplanting and wheat harvests are labor-intensive and time-critical compared with other production phases. In addition to hiring outside labor or seeking social services from agricultural companies, famers can invest in machinery if they can acquire enough funding.

\section{The Regression Results and Analysis}

In this section, we test hypotheses $\mathrm{H} 1$ to $\mathrm{H} 3$ based on the above empirical models and analysis.

\subsection{Social Trust Formation: Community Trust and Personal Trust}

As a means of accumulating social capital, gift giving may work differently for different types of social capital accumulated through multiple channels. We separate social trust into community trust and personal trust and then test the role that gift giving plays for each. The results are shown in Table 2.

Table 2. Effect of gift giving on social trust in two levels.

\begin{tabular}{|c|c|c|c|c|}
\hline \multirow{2}{*}{ Variables } & \multicolumn{2}{|c|}{ Community Trust } & \multicolumn{2}{|c|}{ Personal Trust } \\
\hline & (1) & (2) & (3) & (4) \\
\hline Gift expenditure (in log) & $\begin{array}{c}0.0315 \\
(0.0210)\end{array}$ & & $\begin{array}{l}0.0405 * \\
(0.0243)\end{array}$ & \\
\hline Gift expenditure per capita (in log) & & $\begin{array}{c}0.0340 \\
(0.0209)\end{array}$ & & $\begin{array}{l}0.0406^{*} \\
(0.0240)\end{array}$ \\
\hline Individual characteristics & control & control & control & control \\
\hline Household characteristics & control & control & control & control \\
\hline Village level characteristics & control & control & control & control \\
\hline Observations & 3653 & 3653 & 3653 & 3653 \\
\hline
\end{tabular}

Notes: All regressions control for household characteristics and village level characteristics with variables described in Table 1. Besides, we also control for the individual characteristics of the respondents, including annual income, education, health condition, age, gender, marital status, whether a local registered resident, whether plan to work outside, whether engaged in agriculture and number of siblings. ${ }^{*},{ }^{* *}$ and ${ }^{* * *}$ indicate significance at the $1 \%, 5 \%$ and $10 \%$ levels, respectively.

The results in Table 2 show that gift giving significantly improves individual-level trust but not community-level trust when controlling for other characteristics at the individual, household, and village levels. Thus, we can conclude that gift giving is mainly conducted as a means of developing trust at the personal level, but not at the community level. Thus, hypothesis $\mathrm{H} 2 \mathrm{~b}$ is supported but $\mathrm{H} 2 \mathrm{a}$ is rejected. This is reasonable because gift giving is mainly conducted on an individual level and can be considered as a personal cost of investing in social capital. 


\subsection{The Efects of Community Trust, Personal Trust, and Gift Giving on Credit Accessments}

Having access to finance is important for rural households, and one of the key functions of social capital is to facilitate funding support. We apply ordinary least squares and the Heckman selection model to the full sample to test how gift spending, community trust, and personal trust affect the amounts that households borrow. The results are shown in Table 3a.

Table 3. (a) Effect of gift giving on total borrowing amount; (b) Effect of gift giving and trust on borrowing channels.

(a)

\begin{tabular}{|c|c|c|c|c|c|c|}
\hline \multirow{3}{*}{ Variables } & \multicolumn{6}{|c|}{ Borrowing Amount (In Log) } \\
\hline & \multicolumn{3}{|c|}{ OlS } & \multicolumn{3}{|c|}{ Heckman Selection Model } \\
\hline & (1) & (2) & (3) & (4) & (5) & (6) \\
\hline \multirow[t]{2}{*}{ Gift expenditure (in log) } & $0.222 * * *$ & $0.222 * * *$ & $0.220 * * *$ & $0.224^{* * *}$ & $0.224^{* * *}$ & $0.220^{* * *}$ \\
\hline & $(0.0242)$ & $(0.0242)$ & $(0.0242)$ & $(0.0246)$ & $(0.0246)$ & $(0.0247)$ \\
\hline Community trust & & 0.0113 & & & -0.00567 & \\
\hline Personal trust & & & $(0.0247)$ & & & $(0.0252)$ \\
\hline Household characteristics & control & control & control & control & control & control \\
\hline Village level characteristics & control & control & control & control & control & control \\
\hline R-squared & 0.166 & 0.167 & 0.168 & & & \\
\hline Rho & & & & 0.1526 & 0.16137 & 0.16263 \\
\hline
\end{tabular}

Notes: The control variables referring to the existence of banks, existence of cooperation organizations and the distance to the nearest town in the first stage of Heckman selection model are excluded in the second stage to ensure the consistent estimation. ${ }^{*},{ }^{* *}$ and ${ }^{* * *}$ indicate significance at the $1 \%, 5 \%$ and $10 \%$ levels, respectively.

(b)

\begin{tabular}{|c|c|c|c|c|}
\hline \multirow{3}{*}{ Variables } & \multicolumn{4}{|c|}{ Borrowing Amount (In Log) } \\
\hline & Informal & Bank & Informal & Bank \\
\hline & (1) & (2) & (3) & (4) \\
\hline \multirow[t]{2}{*}{ Gift expenditure (in log) } & $0.208^{* * *}$ & 0.028 & $0.204^{* * *}$ & 0.012 \\
\hline & $(0.0468)$ & $(0.1170)$ & $(0.0467)$ & $(0.1240)$ \\
\hline Community trust & 0.013 & $0.177^{*}$ & & \\
\hline Personal trust & & & $(0.0311)$ & $(0.0604)$ \\
\hline Household characteristics & control & control & control & control \\
\hline Village level characteristics & control & control & control & control \\
\hline Observation & 2066 & 222 & 2066 & 222 \\
\hline R-square & 0.154 & 0.456 & 0.154 & 0.456 \\
\hline
\end{tabular}

Note: The borrowing amount is categorized by the sources of loans including formal loan from the bank and informal loan from means other than bank loan. ${ }^{*}{ }^{* *}$ and ${ }^{* * *}$ indicate significance at the $1 \%, 5 \%$ and $10 \%$ levels, respectively.

The results in Table 3a show that gift giving plays an important role in households' credit accessibility. More spending on gifts brings more capital resources, with part of its fuction working through personal trust. The coefficient of community trust is not significant in this full sample test. The coefficient of Gift expenditure in the ordinary least squares regression model (1) is the same as that in model (2), which tests the effect of Community trust, but greater than that in model (3), which tests the effect of Personal trust. Similar results are found for the Heckman selection regressions in models (4) to (6). Thus, gift giving can be used as a tool to construct and maintain networking social capital as well as trust and can increase social ties alongside those created through blood lineage, marriage, norms, and legal contracts. The most interesting finding is that strong trust is not necessary because 
gift giving ensures that valuable signals are sent, the relational bonds are stronger, and the gift will be repaid.

We then explore the effects of gift giving for the different funding channels. We consider banks as formal financial institutions and the other channels as informal ones. The results in Table $3 b$ show that expenditures on gifts and personal trust help secure credit via informal channels, while community trust provides significant help in obtaining formal loans from banks, possibly because the formal financial institutions face high individual investigation costs when issuing loans and thus usually take community trust as an important signal when evaluating a borrower's creditworthiness. In particular, the credit officers in banks are reluctant to accept gifts from farmers because this type of activity is defined as bribery. In contrast, informal lenders have no moral or legal barriers to taking gifts and usually accept them as a mean of enhancing the relationship. These results thus support hypothesis $\mathrm{H} 2$.

Because the purpose of a loan can also affect lending, we subdivide the loan amount based on the most common requirements, namely production, housing, consumption, education, medical expenses, and other factors. Table $4 \mathrm{a}, \mathrm{b}$ show the results for how community trust, personal trust, and gift spending affect the borrowing amounts for the different requirements. These results also support hypothesis $\mathrm{H} 2$.

Table 4a shows that community trust has a negative effect on the borrowing amount for production and education but has no significant effect on the other purposes, which means that community trust reduces the demand of borrowing for production and education. In this case, the higher level of community trust may indicate more harmonious relationships in the village. Families living in such communities may rely more on mutual assistance mechanisms as a substitution for social services or material inputs. In China, high level of community trust in villages are mostly the product of long-inherited traditional culture. An important characteristic of this culture is its emphasis on education and respect for knowledge. The demand for education funds mostly occurs when students obtain the opportunity beyond the compulsory education level, such as college. Under this circumstance, in China, villagers sometimes give Hongbao, which is a red envelope with money in it, to the needed families. Some villages even collect donation and set up public education fund to cover the tuition fee for students who get accept to colleges in Guangdong, a province which is famous for inheriting traditional culture in China. It is reasonable to presume that villages with high community trust are more likely to set up such funds, and that more villagers give larger Hongbao than those with low trust. Thus, households living in high trust community borrowing less for education. The decline in credit for production and education shows that community trust contributes to risk sharing activities. However, higher expenditure on gifts helps in acquiring higher loan amounts for production and house purposes instead of three other purposes. This means that a gift giving can be more used as social capital investment to pursue higher profit instead of risk sharing.

Table $4 \mathrm{~b}$ shows how personal trust affects the demand for the different goals. The results indicate that personal trust increases the amounts borrowed for consumption and medical expenses. Compared to loans for production and house construction or repairs, consumption and medical expenses do not bring future returns for the money borrowed and thus depend more on personal trust. In addition to social capital such as trust, gift expenditure helps household access credit for accumulative activities such as production and house construction or repairs.

Overall, the results in Table 4a,b show that personal trust mainly helps in securing loans for unprofitable purposes and thus support hypothesis H3. Compared with the loans for consumption and medical expenses, personal trust does not significantly affect the size of the loans granted for educational purposes, which may because tuition is usually relatively fixed and limited compared with the other kinds of demands. 
Table 4. (a) Effect of gift giving and community trust on borrowing purpose. (b) Effect of gift giving and personal trust on borrowing purpose.

(a)

\begin{tabular}{|c|c|c|c|c|c|c|}
\hline \multirow{3}{*}{ Variables } & \multicolumn{6}{|c|}{ Borrowing Amount (In Log) } \\
\hline & Production & House & Consumption & Education & Medical & Other \\
\hline & (1) & (2) & (3) & (4) & (5) & (6) \\
\hline \multirow[t]{2}{*}{ Gift expenditure (in log) } & $0.253 * *$ & $0.127^{* *}$ & 0.034 & 0.199 & 0.111 & $0.554^{* * *}$ \\
\hline & $(0.0493)$ & $(0.0493)$ & $(0.4150)$ & $(0.1334)$ & $(0.0888)$ & $(0.1280)$ \\
\hline \multirow[t]{2}{*}{ Community trust } & $-0.145^{* *}$ & 0.034 & 0.285 & $-0.137^{*}$ & 0.009 & -0.038 \\
\hline & $(0.0704)$ & $(0.0396)$ & $(0.2015)$ & $(0.0760)$ & $(0.0830)$ & $(0.0894)$ \\
\hline Household characteristics & control & control & control & control & control & control \\
\hline Village level characteristics & control & control & control & control & control & control \\
\hline Observation & 348 & 1157 & 76 & 224 & 398 & 371 \\
\hline R-square & 0.435 & 0.147 & 0.782 & 0.368 & 0.236 & 0.355 \\
\hline
\end{tabular}

Notes: The borrowing amount is categorized by loan uses for production, house, consumption, education, medical care, and other subjects. ${ }^{*}, * *$ and ${ }^{* *}$ indicate significance at the $1 \%, 5 \%$ and $10 \%$ levels, respectively.

(b)

\begin{tabular}{|c|c|c|c|c|c|c|}
\hline \multirow{3}{*}{ Variables } & \multicolumn{6}{|c|}{ Borrowing Amount (In Log) } \\
\hline & Production & House & Consumption & Education & Medical & Other \\
\hline & (1) & (2) & (3) & (4) & (5) & (6) \\
\hline \multirow{2}{*}{ Gift expenditure (in log) } & $0.256^{* *}$ & $0.126^{* *}$ & 0.078 & 0.201 & 0.113 & $0.550 * * *$ \\
\hline & $(0.1210)$ & $(0.0495)$ & $(0.4040)$ & $(0.1320)$ & $(0.0871)$ & $(0.1280)$ \\
\hline \multirow[t]{2}{*}{ Personal trust } & -0.077 & 0.026 & $0.234 *$ & 0.074 & $0.132 * *$ & 0.018 \\
\hline & $(0.0666)$ & $(0.0332)$ & $(0.1300)$ & $(0.0679)$ & $(0.0632)$ & $(0.0837)$ \\
\hline Household characteristics & control & control & control & control & control & control \\
\hline Village level characteristics & control & control & control & control & control & control \\
\hline Observation & 348 & 1157 & 76 & 224 & 398 & 371 \\
\hline R-square & 0.435 & 0.147 & 0.782 & 0.368 & 0.236 & 0.355 \\
\hline
\end{tabular}

Note: The borrowing amount is categorized by loan uses for production, house, consumption, education, medical care and other subjects. It is also categorized by the sources of loans including formal loan from the bank and informal loan from means other than bank loan. ${ }^{*}{ }^{* *}$ and ${ }^{* *}$ indicate significance at the $1 \%, 5 \%$ and $10 \%$ levels, respectively.

\section{Discussion and Conclusions}

This paper examines how social activities such as gift giving help to build social capital and enhance its function in facilitating access to formal and informal credit for rural households. Compared with the function of transmitting goodwill and altruism, gift also has the important economic function of promoting trust network construction and facilitating informal loans, especially for low-income rural families. The results show that, while gift giving as an individual form of exchange can strengthen social trust, it mainly improves personal trust rather than community trust. In addition, our findings show the mechanisms of the different levels of trust. Community trust increases the likelihood of accessing credit from banks as a formal channel, whereas personal trust increases the likelihood of securing informal lending. When considering the purpose of the loans, the estimation results show that personal trust helps more in securing access to loans for consumption and medical expenses, which provides further support for the research showing that social capital plays a strong risk-sharing role in rural areas $[14,30,36,37]$. In particular, gift giving plays an independent role in addition to social trust in facilitating informal cooperation. It not only improves the overall amount of informal credit but also facilitates wealth accumulation by improving access to funding for production and house construction and maintenance. As individuals embedded in the society, farmers often need the cooperation or support of others in their economic activities. The effects of human pro-sociality and trust on economic behavior have been extensively studied over the past few decades. Behaviors that can increase social bonding include motivation altruism, reciprocity, inequality aversion, guilty as well as social network building activities like gift giving, favor exchange, and so on [38-42]. This paper fits in the literature by providing evidence about how people use gift giving as a mean to increase social capital within their social networks to achieve economic activities. It should be noted, however, that our research is based on the behavior of developing low-income farmers. For the more developed areas, the function 
of gifts will be different. In addition, other factors also affect the construction of social trust, such as cultural environment, income differences, religious beliefs and so on. For example, conspicuous gift giving, risk-sharing gift giving, and giving to build a social capital reserve network are likely to have different effects in these contexts.

Author Contributions: T.Z.: conceptualization, supervision, methodology, writing-original draft preparation, funding acquisition; H.L.: methodology, formal analysis, writing - original draft preparation; P.L.: data curation, writing - review and editing. All authors have read and agreed to the published version of the manuscript.

Funding: This research was supported by the Planning Projects of Humanities and Social Sciences Foundation of Ministry of Education of China (No. 15XJA790006), Guangdong Provincial University Innovation Team Project (No. 2017WCXTD001), the Ministry of Education (China) Key Research Center Projects (No. 16JJD630009, 16JJD630011), and National Natural Science Foundation of China (No. 71873149).

Acknowledgments: Data used in this paper is from the China Labor-force Dynamics Survey (CLDS) by the Center for Social Science Survey at Sun Yat-sen University in Guangzhou, China. The opinions are the author's alone. Please refer to http://css.sysu.edu.cn for more information about the CLDS data.

Conflicts of Interest: The authors declare no conflict of interest. The founding sponsors had no role in the design of the study; in the collection, analyses, or interpretation of data; in the writing of the manuscript, and in the decision to publish the results.

\section{References}

1. Putnam, R.D. Tuning in, tuning out: The strange disappearance of social capital in America. Polit. Sci. Polit. 1995, 28, 664-683. [CrossRef]

2. Knack, S.; Keefer, P. Does social capital have an economic payoff? A cross-country investigation. Q. J. Econ. 1997, 112, 1251-1288. [CrossRef]

3. Hayami, Y. Social capital, human capital and the community mechanism: Toward a conceptual framework for economists. J. Dev. Stud. 2009, 45, 96-123. [CrossRef]

4. Ishise, H.; Sawada, Y. Aggregate returns to social capital: Estimates based on the augmented-Solow model. J. Macroecon. 2009, 31, 376-393. [CrossRef]

5. Karlan, D.; List, J.A. Does price matter in charitable giving? Evidence from a large-scale natural field experiment. Am. Econ. 2007, 97, 1774-1793. [CrossRef]

6. Paal, B.; Wiseman, T. Group insurance and lending with endogenous social collateral. J. Dev. Econ. 2011, 94, 30-40. [CrossRef]

7. Sun, H.; Hartarska, V.; Zhang, L.; Nadolnyak, D. The influence of social capital on farm household's borrowing behavior in rural China. Sustainability 2018, 10, 4361. [CrossRef]

8. Berg, J.; Dickhaut, J.; McCabe, K. Trust, reciprocity, and social history. Game. Econ. Behav. 1995, 10, 122-142. [CrossRef]

9. Guiso, L.; Sapienza, P.; Zingales, L. The role of social capital in financial development. Am. Econ. Rev. 2004, 94, 526-556. [CrossRef]

10. Chen, S.H.; Chie, B.T.; Zhang, T. Network-based trust games: An agent-based model. JASSS 2015, 18, 5. [CrossRef]

11. Platteau, J.P. Behind the market stage where real societies exist-part I: The role of public and private order institutions. J. Dev. Stud. 1994, 30, 33-577. [CrossRef]

12. Shoji, M.; Aoyagi, K.; Kasahara, R.; Sawada, Y.; Ueyama, M. Social capital formation and credit access: Evidence from Sri Lanka. World Dev. 2012, 40, 2522-2536. [CrossRef]

13. DeYoung, R.; Glennon, D.; Spong, K. Small business lending and social capital: Are rural relationships different? Work. Pap. 2012. Available online: https://www.stlouisfed.org/ \{\}/media/files/pdfs/banking/cbrc2013/dgns_2012_sba_lending.pdf (accessed on 31 December 2019).

14. Kinnan, C.; Townsend, R. Kinship and financial networks, formal financial access, and risk reduction. Am. Econ. Rev. 2012, 102, 289-293. [CrossRef]

15. Wang, R. Who should I share risk with? Gifts can tell: Theory and evidence from rural China. CentER Discuss. Pap. Ser. 2016, 3, 1-44. [CrossRef]

16. Rosenzweig, M.R.; Stark, O. Consumption smoothing, migration, and marriage: Evidence from rural India. J. Polit. Econ. 1989, 97, 905-926. [CrossRef] 
17. Coate, S.; Ravallion, M. Reciprocity without commitment: Characterization and performance of informal insurance arrangements. J. Dev. Econ. 1993, 40, 1-24. [CrossRef]

18. Barslund, M.; Tarp, F. Formal and informal rural credit in four provinces of Vietnam. J. Dev. Stud. 2008, 44, 485-503. [CrossRef]

19. Nissanke, M.; Aryeetey, E. Financial Integration and Development: Liberalization and Reform in Sub-Saharan Africa; Psychology Press: London, UK, 1998.

20. Das Gupta, C. India: Democratic becoming and Combined Development. In Democracy in Developing Countries: Asia; Diamond, L., Linz, J.J., Lipset, S.M., Eds.; Lynne Riener: Boulder, CO, USA, 1989; Volume 3, pp. 53-104.

21. Besley, T.; Coate, S. Group lending, repayment incentives and social collateral. J. Dev. Econ. 1995, 46, 1-18. [CrossRef]

22. Karlan, D.; Mobius, M.; Rosenblat, T.; Szeidl, A. Trust and social collateral. Q. J. Econ. 2009, 124, $1307-1361$. [CrossRef]

23. Carter, M.R.; Castillo, M. Trustworthiness and social capital in South Africa: Analysis of actual living standards data and artifactual field experiments. Econ. Dev. Cult. Chang. 2011, 59, 695-722. [CrossRef]

24. Fafchamps, M.; Gubert, F. The formation of risk sharing networks. J. Dev. Econ. 2007, 83, 326-350. [CrossRef]

25. Fafchamps, M.; Lund, S. Risk-sharing networks in rural Philippines. J. Dev. Econ. 2003, 71, $261-287$. [CrossRef]

26. Ligon, E.; Thomas, J.P.; Worrall, T. Informal insurance arrangements with limited commitment: Theory and evidence from village economies. Rev. Econ. Stud. 2002, 69, 209-244. [CrossRef]

27. Murgai, R.; Winters, P.; Sadoulet, E.; Janvry, A.D. Localized and incomplete mutual insurance. J. Dev. Econ. 2002, 67, 245-274. [CrossRef]

28. Kimball, M.S. Farmers' cooperatives as behavior toward risk. Am. Econ. Rev. 1988, 78, 224-232. [CrossRef]

29. De Weerdt, J.; Dercon, S. Risk-sharing networks and insurance against illness. J. Dev. Econ. 2006, 81, 337-356. [CrossRef]

30. Genicot, G.; Ray, D. Group formation in risk-sharing arrangements. Rev. Econ. Stud. 2003, 70, 87-113. [CrossRef]

31. Madestam, A. Informal finance: A theory of moneylenders. J. Dev. Econ. 2014, 107, 157-174. [CrossRef]

32. Banerjee, A.V.; Duflo, E. The economic lives of the poor. J. Econ. Perspect. 2007, 21, 141-167. [CrossRef]

33. Turvey, C.G.; Kong, R. Informal lending amongst friends and relatives: Can microcredit compete in rural China? China Eco. Rev. 2010, 21, 544-556. [CrossRef]

34. Heckman, J.J. Sample selection bias as a specification error. Econometrica 1979, 47, 153-161. [CrossRef]

35. Baron, R.M.; Kenny, D.A. The Moderator-mediator variable distinction in social psychological research: Conceptual, strategic, and statistical considerations. J. Pers. Soc. Psychol. 1986, 51, 1173. [CrossRef] [PubMed]

36. Imai, K.; Keele, L.; Tingley, D.; Yamamoto, T. Unpacking the black box of causality: Learning about causal mechanisms from experimental and observational studies. Am. Polit. Sci. Rev. 2011, 105, 765-789. [CrossRef]

37. Attanasio, O.; Barr, A.; Cardenas, J.C.; Genicot, G.; Meghir, C. Risk pooling, risk preferences, and social networks. Am. Econ. J. Appl. Econ. 2012, 4, 134-167. [CrossRef]

38. Levine, D.K. Modeling altruism and spitefulness in experiments. Rev. Econ. Dynam. 1998, 1, 593-622. [CrossRef]

39. Ferrara, E.L. Kin groups and reciprocity: A model of credit transactions in Ghana. Am. Econ. Rev. 2003, 93, 1730-1751. [CrossRef]

40. Engelmann, D.; Strobel, M. Inequality aversion, efficiency, and maximin preferences in simple distribution experiments. Am. Econ. Rev. 2004, 94, 857-869. [CrossRef]

41. Li, H.; Rosenzweig, M.; Zhang, J. Altruism, favoritism, and guilt in the allocation of family resources: Sophie's choice in Mao's mass send-down movement. J. Polit. Econ. 2010, 118, 1-38. [CrossRef]

42. Matthew, O.J.; Rodriguez-Barraquer, T.; Tan, X. Social capital and social quilts: Network patterns of favor exchange. Am. Econ. Rev. 2012, 102, 1857-1897. [CrossRef]

(C) 2020 by the authors. Licensee MDPI, Basel, Switzerland. This article is an open access article distributed under the terms and conditions of the Creative Commons Attribution (CC BY) license (http://creativecommons.org/licenses/by/4.0/). 